\title{
Aging as a predictor of nursing workload in Intensive Care Unit: results from a Brazilian Sample
}

\author{
Envelhecimento como um preditor de carga de trabalho de enfermagem em \\ Unidade de Terapia Intensiva: resultados de uma amostra brasileira \\ Envejecimiento como predictor de la carga de trabajo de enfermería en \\ Unidad de Cuidados Intensivos: resultados de una muestra brasileña
}

Renata Eloah de Lucena Ferretti-Rebustini ${ }^{1}$, Lilia de Souza Nogueira ${ }^{1}$, Rita de Cassia Gengo e Silva ${ }^{1}$, Vanessa de Brito Poveda$^{1}$, Selma Pinheiro Machado ${ }^{2}$, Elaine Machado de Oliveira ${ }^{2}$, Rafaela Andolhe ${ }^{3}$, Katia Grillo Padilha ${ }^{1}$

How to cite this article:

Ferretti-Rebustini REL, Nogueira LS, Silva RCG, Poveda VB, Machado SP, Oliveira EM, et al. Aging as a predictor of nursing workload in intensive care unit: results from a Brazilian Sample. Rev Esc Enferm USP. 2017;51:e03216. DOI: http://dx.doi.org/10.1590/S1980-220X2016036903216

${ }^{1}$ Universidade de São Paulo, Escola de Enfermagem, Departamento de Enfermagem Médico-Cirúrgica, São Paulo, SP, Brazil.

${ }^{2}$ Universidade de São Paulo, Escola de Enfermagem, Programa de PósGraduação em Enfermagem na Saúde do Adulto, São Paulo, SP, Brazil.

${ }^{3}$ Universidade Federal de Santa Maria, Departamento de Enfermagem, Santa Maria, RS, Brazil.

\begin{abstract}
Objective: Verify if aging is an independent predictor of NW in ICU, according to age groups, and its predictive value as a determinant of NW in ICU. Methods: Study was conducted from 2012 to 2016. A convenience sample composed by patients (age $\geq 18$ ) admitted to nine ICU belonging to a Brazilian hospital, was analyzed. Age was assumed as an independent variable and NW (measured by the Nursing Activities Score - NAS) as dependent. Linear regression model and ROC curve were used for the analysis. Results: 890 participants (361 older people), mostly males (58.1\%). The mean NAS score was higher among older participants in comparison to adults $(p=0.004)$ but not within categories of aging $(p=0.697)$. Age was responsible for $0.6 \%$ of NAS score. Each year of age increases NAS score in 0.081 points $(p=0.015)$. However, age was not a good predictor of NAS score (AUC $=0.394 ; \mathrm{p}=0.320$ ). Conclusion: The care of older people in ICU is associated with an increase in NW, compared to adults. Aging can be considered an associated factor but not a good predictor of NW in ICU.
\end{abstract}

DESCRIPTORS

Aging; Aged; Nursing; Workload; Intensive Care Units.
Corresponding author:

Renata Eloah de Lucena Ferretti-Rebustini

Av. Dr. Enéas de Carvalho Aguiar, 419

$3^{\circ}$ floor, Room 354 - Cerqueira César

CEP 05403-000 - São Paulo, SP, Brazil

reloah@usp.br 


\section{INTRODUCTION}

The number of older people ( $>60$ years) in Intensive Care Units (ICU) is increasing substantially, as population ages. The mean age of patients in ICU is higher than it used to be. This is not an exclusive Brazilian phenomenon but a worldwide one: older people account for at least $50 \%$ of occupation in ICU and the number of oldest-old patients ( $\geq 80$ years) is significant ${ }^{(1-5)}$. Nurses and all the health care team should be prepared to the care of these patients in acute and critical conditions.

Along time, the concept that age has to be considered during decision of whose patients should be admitted to ICU is changing. Nowadays, advanced age itself is not a contraindicative criterion for admission in ICU and several factors are considered ${ }^{(6-7)}$. Decisions have to be based on the condition of the person and the potential to benefit from ICU resources leading to recovery. Health professionals have to concentrate efforts in preventing older people to evolve into a critical condition indicative of ICU admission. Once it is not possible, they should be beneficiated from all available ICU resources, aiming to achieve expected outcomes of recovery and discharge, as soon as possible.

The specialized care of older people in the ICU requires skilled nurses, knowledgeable of specificities inherent to senescence and senility ${ }^{(1,4,8-13)}$. This is one of the most important determinants of quality of care and patient safety in ICU, when considering the intensive care of older people. Thus, one might think that the nursing process directed to the care of older people in critical condition is associated with an increase in nursing workload (NW), as they tend to have more morbidity, more risk of mortality and, in some situations, more dependency.

To date, some published researches explored the analysis of burden among caregivers of older people discharged from ICU. Therewithal, associated factors for NW in ICU have also been described ${ }^{(14-17)}$. The great majority of these previous studies focused on determining predictors of NW in adult patients admitted to ICU. Nonetheless, studies that aimed to determine predictors of NW in older people populations worldwide are lacking. In Brazil, one study ${ }^{(18)}$ analyzed predictors of NW among older patients admitted to ICU. Findings evidenced that severity, type of admission and old age (70-79 years) were determinants of NW. The predictive value of age to determine $\mathrm{NW}$ was not tested.

As far as it is known, no previous study analyzed the effect of age in NW in a representative sample, stablishing comparisons with other age groups. Thus, we aimed to verify whether age is an independent predictor of NW in ICU, according to age groups, and to verify its predictive value as a determinant of NW in ICU.

\section{METHOD}

\section{Study Design, Settings and Participants}

This was a single center, retrospective cohort study. Study was conducted from 2012 to 2016. A convenience sample was used including patients (age $\geq 18$ ) who were admitted to nine different specialties ICU (Surgery, Internal Medicine,
Clinical Emergency, Infectious Diseases, Nephrology, Neurology, Pulmonology, Trauma and Burn) for clinical or surgical treatment, at a large Brazilian public general hospital. Data was collected from review of all available medical charts.

\section{StUdV VARIABLES AND DATA ANALYSIS}

In this study we assumed age as an independent variable and the Nursing Activities Score (NAS), an instrument for measuring NW in ICU, as dependent. Other variables were analyzed to characterize the sample: sex, Charlson Comorbidity Index (CCI), condition of the patient according to death risk calculated by the Simplified Acute Physiology Score II (SAPS II) and Logistic Organ Dysfunction System (LODS), type of admission, length of stay (LOS) in ICU, type of ICU, and outcome (discharged or death) in critical care unit.

For the analysis, sample was stratified into age groups. To test if there was a difference in NW among adults vs older people, we stratified age in two subgroups: adults $(<60$ years old) an older people ( $\geq 60$ years old). To test if there were differences in NW into older people age subgroup, we stratified age in three subgroups: young old (60 F 70), old $(70+80)$ and oldest old $(\geq 80)$. We also compared the four age groups: adults, young old, old, older old.

The descriptive analysis was conducted by using measures of central tendency and dispersion. T-Student test was used to compare NW between adults and older people. The Levene test was applied to identify the mean NAS distribution (normal or non-normal) among the three older people age groups. To compare the NW among the older people age group and among the four age groups, we applied One Way Anova with post-hoc analysis. The Fisher's exact test was used to test associations among nominal variables. A Linear regression model (assuming age as a continuous independent variable) was built to identify if age is a predictor of NW.To determine whether age is a good predictor of NW, the area under the curve (AUC) with $95 \%$ confidence interval was estimated. For this, we used the NAS cut-off point obtained by a classification tree. Age was considered a good predictor of NW if the AUC was $\geq 0.70$. All tests were two-tailed and the p-value was set at 0.05 .

\section{Ethical STATEMENT}

The study protocol and waiver of consents were approved by the local Ethics Committee (process number 0196/2011) and the study was conducted in accordance with the Declaration of Helsinki.

\section{RESULTS}

Sample consisted of 890 participants (529 adults and 361 older people), mostly males (58.1\%), with mean age of 54.1 \pm 17.4 . Table 1 presents samples' characteristics.

The mean NAS score was higher among older people $(p=0.004)$ in comparison to adults. This difference remains even when adults were compared to the stratified older people age group $(p=0.027)$. It was observed that NAS has 
a normal distribution among the three older people age groups (Levene $=3.58 ; \mathrm{p}<0.020$ ), and no statistical difference was found among them $(\mathrm{p}=0.697)$. Post-hoc analysis certified that no difference in mean NAS score within older people age group exists, what indicates that there is no need to categorize older patients in age groups when analyzing nursing workload. The best NAS cut-off point was 52.0, as shown in Figure 1.

Table 1 - Distribution of participants according to some selected characteristics, according to age group - São Paulo, SP, Brazil, $2012-2016$.

\begin{tabular}{|c|c|c|c|c|c|}
\hline & $<60$ & $60+$ & $70+$ & $80+$ & $p$-value \\
\hline \multicolumn{6}{|l|}{ Sex $(n ; \%)$} \\
\hline Men & $320 ; 36.0$ & $114 ; 12.8$ & $61 ; 6.9$ & $22 ; 2.5$ & \multirow{2}{*}{$0.001^{*}$} \\
\hline Women & $209 ; 23.5$ & $68 ; 7.6$ & $60 ; 6.7$ & $36 ; 4.0$ & \\
\hline Age $($ mean $\pm S D)$ & $42.6 \pm 11.8$ & $64.5 \pm 2.6$ & $74.1 \pm 2.9$ & $84.9 \pm 4.1$ & $<0.001^{\sharp}$ \\
\hline Charlson $($ mean $\pm S D)$ & $1.8 \pm 1.9$ & $1.8 \pm 2.0$ & $1.9 \pm 2.0$ & $1.8 \pm 1.6$ & $0.774^{*}$ \\
\hline SAPS2 $-1^{\text {st }}$ day $($ mean \pm SD $)$ & $32.3 \pm 13.6$ & $31.8 \pm 13.6$ & $33.0 \pm 16.6$ & $32.0 \pm 14.4$ & $0.902^{*}$ \\
\hline LODS $-1^{\text {st }}$ day $($ mean $\pm S D)$ & $5.2 \pm 3.7$ & $5.1 \pm 4.0$ & $5.3 \pm 4.3$ & $4.7 \pm 3.7$ & $0.722^{\#}$ \\
\hline NAS $($ mean $\pm S D)$ & $69.9 \pm 13.9$ & $73.2 \pm 18.2$ & $71.9 \pm 13.1$ & $73.8 \pm 7.7$ & $0.027^{\#}$ \\
\hline LOS-ICU $($ mean $\pm S D)$ & $7.0 \pm 10.9$ & $6.3 \pm 8.9$ & $7.2 \pm 7.7$ & $7.3 \pm 8.3$ & $0.808^{\#}$ \\
\hline \multicolumn{6}{|l|}{ Type of ICU (n;\%) } \\
\hline Clinical & $171 ; 19.2$ & $65 ; 7.3$ & $55 ; 6.2$ & $20 ; 2.2$ & \multirow{3}{*}{$0.799 *$} \\
\hline Surgical & $221 ; 24.8$ & $64 ; 7.2$ & $41 ; 4.6$ & $27 ; 3.0$ & \\
\hline Specialized & $137 ; 15.4$ & $53 ; 6.0$ & $25 ; 2.8$ & $11 ; 1.2$ & \\
\hline \multicolumn{6}{|l|}{ Type of admission $(n ; \%)$} \\
\hline Clinical & $326 ; 36.6$ & $114 ; 12.8$ & $89 ; 10.0$ & $38 ; 4.3$ & \multirow{3}{*}{$0.078^{*}$} \\
\hline Surgical (elective) & $95 ; 10.7$ & $38 ; 4.3$ & $18 ; 2.0$ & $7 ; 0.8$ & \\
\hline Surgical (emergency) & $108 ; 12.1$ & $30 ; 3.4$ & $14 ; 1.6$ & $13 ; 1.5$ & \\
\hline \multicolumn{6}{|l|}{ Outcome in ICU } \\
\hline Discharged & $441 ; 49.6$ & $132 ; 14.8$ & $84 ; 9.4$ & $41 ; 4.6$ & \multirow{2}{*}{$<0.001 *$} \\
\hline Death & $88 ; 9.9$ & $50 ; 5.6$ & $37 ; 4.2$ & $17 ; 1.9$ & \\
\hline
\end{tabular}

\# Anova; * Fischer exact test

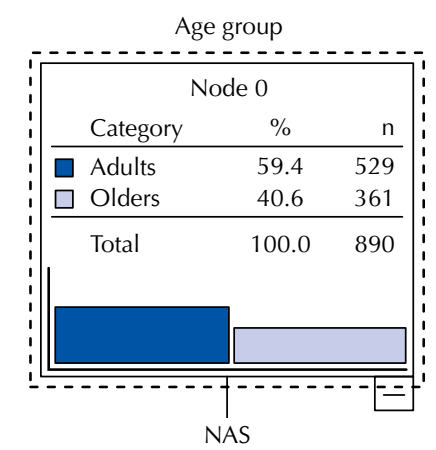

Adj. P-value $=0.041$. Chi-square $=7$.

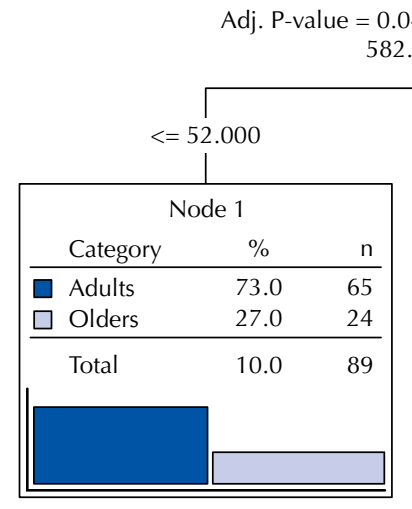

582. $\mathrm{df}=1$

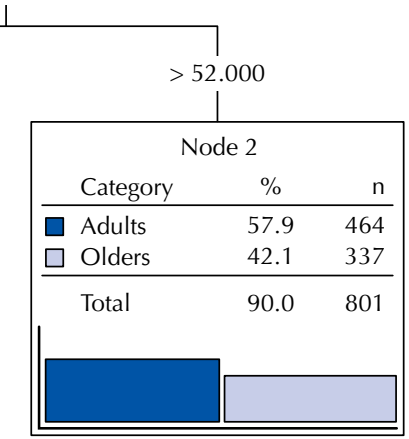

Figure 1 - Classification tree for determining the cut-off point for NAS score according to age group (adults vs older people) - São Paulo, SP, Brazil, 2012-2016.
Age accounts for only $0.6 \%$ of the NAS score. Each year of age increases NAS score in 0.081 points $(p=0.015)$, but it cannot be considered a good predictor of nursing workload, once its AUC is insignificant and below the theoretical limit $(\mathrm{AUC}=0.394 ; \mathrm{CI} 0.202-0.587 ; \mathrm{p}=0.320)$, considering a cut-off point of 52.0 (Figure 2; Table 2).

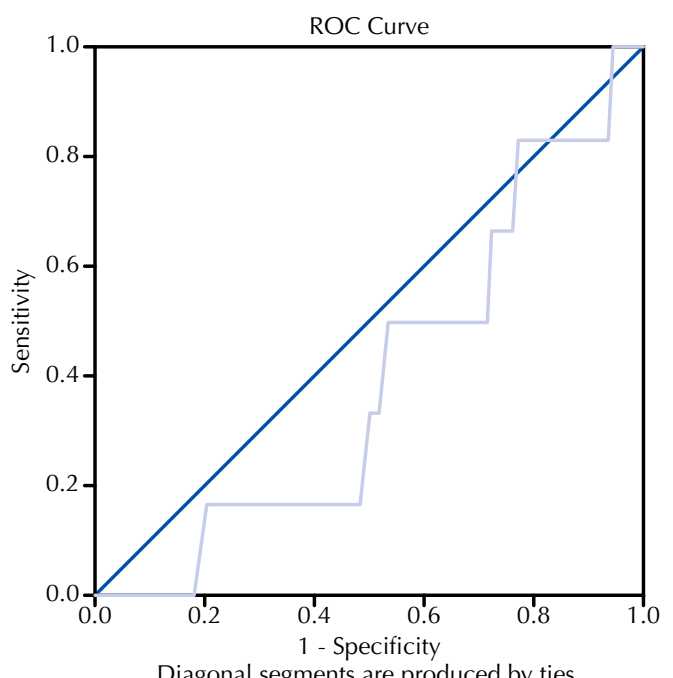

Diagonal segments are produced by ties.

Figure 2 - Receiver Operating Characteristic Curve for predictive ability of age to best determine high nursing workload (NAS>52.0) in intensive care unit - São Paulo, SP, Brazil, 2012-2016. 
Table 2 - Linear regression model for age as predictor of Nursing Workload - São Paulo, SP, Brazil, 2012-2016.

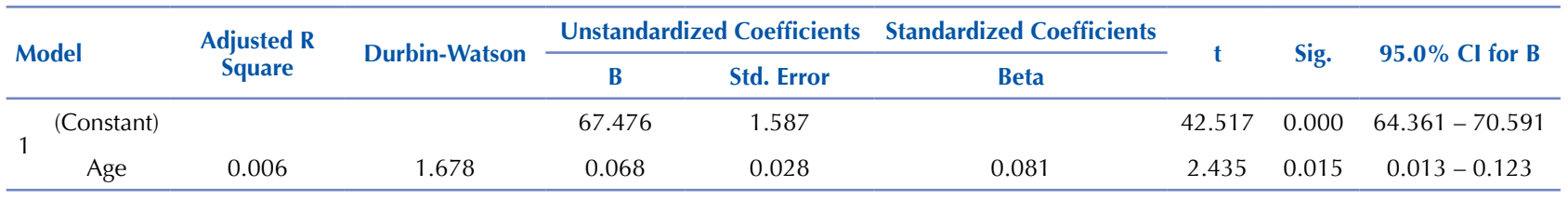

Predictor: Age (measured continuously); Dependent Variable: NAS

\section{DISCUSSION}

The results of the present study evidenced that the care of older people in ICU is associated with a higher NW, compared to adults. Despite the results pointed age as an independent predictor of NW in ICU, the strength of this causative relation was not of higher importance. The evidences found indicate that age accounts for a very modest part of NW; is responsible for very little difference in NAS score; and has no discrimination ability to predict high NW in ICU. On the other hand, when analyzing only older people group, age was not an independent predictor of NW in ICU. It means that despite the association, no causative relation can be stablished between older age groups (60+; $70+; 80+)$ and NW. In other words, NW among older people is higher when compared to adults, but advanced age is not an exclusive determinant of higher NW in ICU.

A previous study ${ }^{(18)}$ analyzed 71 patients admitted to ICU and found that there was no significant difference of NW in older age groups, what is consistent to our results. They did not investigate NW among older patients in comparison to adults. Nonetheless, they found an increased odds ratio (4.56) for having higher NW among septuagenarians. In another study ${ }^{(19)}$ no difference between the mean NAS scores for older (66.44\%) and adult (66.33\%) patients admitted to an ICU was found. A study that analyzed 600 patients ${ }^{(20)}$ and compared the NW required by adult ( $\geq 18$ and $<60$ years), older $(\geq 60$ and $<80$ years) and oldest-old ( $\geq 80$ years) showed that the NW measured by NAS upon admission at the ICU (first 24 hours) was similar among age groups. At discharge, a statistically significant difference was found among groups and this difference occurred between adult (NAS=50.37) and older (NAS=55.85) patients.

No other study was found to enlarge comparisons with our findings, considering NW. However, it was possible to observe that our sample's characteristics was similar to other previous studies in terms of: proportion of older people, gender distribution, type of treatment, comorbidity burden, length of stay in ICU, severity and mortality ${ }^{(21-22)}$.

In the present study, we specifically addressed age as a predictor of NW in ICU. The importance of NW in ICU in remarkable, mainly because of its association to adverse events ${ }^{(23)}$ that can affect patient's safety and increase mortality $^{(23-25)}$. In ICU, more than $50 \%$ of the occurrence of adverse events are in older people ${ }^{(26)}$, but whether it is determined by NW is yet to be investigated.

Another point to discuss is that by fixing age threshold, commonly used to categorize older people into groups, no association to NW was observed. While this categorization of age may be considered a 'bad concept' by some gerontologists, it helps to recognize heterogeneities within the old age. Old age comprehends a very long life period in a way that an old person with 65 years may be different from another with 85 years, in terms of physiologic aging. Physiologic organ reserve and tolerance to treatment decreases along aging and this have to be considered when caring for older people in ICU, otherwise adverse events may happen and patient safety may be compromised. Even so, nurses have to consider that chronologic age and physiologic age may not correspond because aging is a heterogeneous process, reinforcing the practice of individualized care.

Once it was a retrospective study, it was not possible to analyze baseline characteristics important to gerontological understanding of older patient's health condition, such as cognitive and functional status. This information was not available in medical records, thus limiting interpretation about the impact of pre-admission dependence presented by the patient to NW, other than clinical condition. Dementia patients who are cognitively and functionally impaired, for example, tend to impose a higher burden to nursing staff, independent of being critically ill.

Surprisingly, the characteristics presented by older patients were very similar to the ones observed in adults, even considering comorbidity burden measured by Charlson Cumulative Index. Probably there was a selection bias related to ICU admission. Although nowadays age, itself, should not be used as a criterion for ICU admission, it is still associated with a decreased likelihood of admission. The oldest-old patients have $67 \%$ less chance of being admitted to ICU than adults ${ }^{(27)}$. As long as we did not assess patients who unfit admission criteria, we lost the possibility to understand whether these older patients with different clinical conditions would impose an even higher NW and change the findings of the present study.

If benefits from ICU directed to older people are not clearly defined and if misconceptions regarding aging and ageism still prevail, potential patients were missing and selection bias occurred. This is particular important to state because it suggests that the phenomenon should be further investigated by research methods directly designed to cover these aspects. Elsewhere, in clinical practice, criteria for determining whose older people shall benefit from ICU have to be established considering the intersection between institutional/ICU practices and gerontological principles.

Care for older people in ICU is epidemiologically proved to increase several times fold, worldwide. In Brazil, $11 \%$ of total population are above 60 's ${ }^{(28)}$. In 2013 , life expectancy at birth was 74.9 years and after the age of 60 it was 21.8 years-old ${ }^{(29)}$. Health life expectancy at birth is 64 years $^{(28)}$. Epidemiology of aging indicates a profile of patients with 
high morbidity with risk of being acute and critically ill ${ }^{(21-}$

22). Critical care nurses will have to cope with gerontological features of aging in their clinical practice

Last but not least, the present findings may contribute to evidence based nursing practice in a way that these results deconstruct the stereotype that older people is responsible for nursing workload in ICU. Although results are not conclusive, because complex interactions among aging, gerontological features and critical condition were not addressed, they can be used to guide actions in practice until further investigations can contribute by refuting or reinforcing the present findings.

\section{CONCLUSION}

The care of older people in ICU is associated with an increase in nursing workload, compared to adults. Aging can be considered an associated factor but not a predictor of nursing workload in ICU. Complex interaction of aging and other factors inherent to this special population and its impact in nursing workload requires further investigations.

\section{RESUMO}

Objetivo: Verificar se a idade é um preditor independente de Carga de trabalho de Enfermagem (CTE) em Unidade de Terapia Intensiva (UTI), de acordo com o grupo etário e qual sua capacidade preditiva como determinante de maior CTE em UTI. Método: O estudo foi realizado entre 2012 e 2016 . Amostra de conveniência composta por pacientes (idade $\geq 18$ ) admitidos em nove UTI de um hospital universitário brasileiro. A idade foi considerada como variável independente e a CTE (mensurada pelo Nursing Activities Score - NAS) como dependente. Os dados foram analisados por meio de análise de regressão linear e curva ROC. Resultados: 890 participantes (361 idosos), em sua maioria homens (58,1\%). A média do NAS foi maior entre os idosos em comparação aos adultos $(p=0,004)$, mas não entre os grupos etários $(p=0,697)$. A idade foi responsável por $0,6 \%$ da pontuação do NAS. Para cada 1 ano de aumento da idade, a pontuação do NAS aumentou em 0,081 pontos $(\mathrm{p}=0,015)$. No entanto, a idade não foi um bom preditor de maior CTE (AUC = 0,394; $\mathrm{p}=0,320$ ). Conclusão: O cuidado de idosos em UTI está associado à maior CTE. A idade pode ser considerada um fator associado, mas não um bom preditor de CTE em UTI.

\section{DESCRITORES}

Envelhecimento; Idoso; Enfermagem; Carga de Trabalho; Unidades de Terapia Intensiva.

\section{RESUMEN}

Objetivo: Verificar si el envejecimiento es un predictor independiente de la Carga de Trabajo de Enfermería (CTE) en la Unidad de Cuidados Intensivos (UCI), según grupos etarios y su valor predictivo como determinante de la CTE en la UCI. Métodos: Se analizó una muestra de conveniencia compuesta por pacientes (edad $\geq 18$ ) ingresados en nueve UCI pertenecientes a un hospital brasileño. La edad se asumió como variable independiente y como variable dependiente la carga de trabajo de enfermería -medida por el sistema Nursing Activities Score (NAS) de puntuación de actividades de enfermería. Para el análisis, se utilizaron el modelo de regresión lineal y la curva ROC. Resultados: 890 participantes (361 adultos mayores), en su mayoría varones (58,1\%). La puntuación NAS promedio fue mayor entre los participantes adultos mayores en comparación con los adultos $(p=0,004)$, pero no en las categorías de envejecimiento $(p=0,697)$. La edad fue responsable del $0,6 \%$ de la puntuación NAS. Cada año de edad aumenta la puntuación NAS en 0,081 puntos ( $\mathrm{p}=0,015)$. Sin embargo, la edad no resultó un buen predictor de la puntuación NAS (AbC=0,394; $\mathrm{p}=0,320)$. Conclusión: El cuidado de los adultos mayores en UCI se asocia con un aumento de la CTE en comparación con los adultos. El envejecimiento puede considerarse un factor asociado, pero no un buen predictor de la CTE en UCI.

\section{DESCRIPTORES}

Envejecimiento; Anciano; Enfermería; Carga de Trabajo; Unidad de Cuidados Intensivos.

\section{REFERENCES}

1. Walker M, Spivak M, Sebastian M. The impact of aging physiology in critical care. Crit Care Nurs Clin North Am. 2014;26(1):7-14.

2. Maillet JM, Guérot E, Novara A, Le Guen J, Lahjibi-Paulet H, Kac G, et al. Comparison of intensive-care-unit-acquired infections and their outcomes among patients over and under 80 years of age. J Hosp Infect. 2014;87(3):152-8.

3. Bell L. The epidemiology of acute and critical illness in older adults. Crit Care Nurs Clin North Am. 2014;26(1):1-5.

4. Amba KT. Delirium in the elderly adult in critical care. Crit Care Nurs Clin North Am. 2014;26(1):139-45.

5. Schrøder MA, Poulsen JB, Perner A. Acceptable long-term outcome in elderly intensive care unit patients. Dan Med Bull. $2011 ; 58(7): A 4297$.

6. Crippen DW. Very elderly patients in the ICU: should there be a line in the sand? Crit Care Med. 2015;43(7):1527-8.

7. Howe DC. Observational study of admission and triage decisions for patients referred to a regional intensive care unit. Anaesth Intensive Care. 2011;39(4):650-8.

8. Boling B. Renal issues in older adults in critical care. Crit Care Nurs Clin North Am. 2014;26(1):99-104.

9. Davis LL. Cardiovascular issues in older adults. Crit Care Nurs Clin North Am. 2014;26(1):61-89.

10. Frederick DE. Pulmonary issues in the older adult. Crit Care Nurs Clin North Am. 2014;26(1):91-7.

11. Gentleman B. Focused assessment in the care of the older adult. Crit Care Nurs Clin North Am. 2014;26(1):15-20.

12. Lach HW, Lorenz RA, L’Ecuyer KM. Aging muscles and joints: mobilization. Crit Care Nurs Clin North Am. 2014;26(1):105-13. 
13. Struble LM, Sullivan BJ, Hartman LS. Psychiatric disorders impacting critical illness. Crit Care Nurs Clin North Am. 2014;26(1):115-38.

14. Padilha KG, Souza RM, Queijo AF, Mendes AM, Reis Miranda D. Nursing Activities Score in the intensive care unit: analysis of the related factors. Intensive Crit Care Nurs. 2008;24(3):197-204.

15. Stafseth SK, Solms D, Bredal IS. The characterization of workloads and nursing staff allocation in intensive care units: a descriptive study using the Nursing Activities Score for the first time in Norway. Intensive Crit Care Nurs. 2011;27(5):290-4.

16. Altafin JAM, Grion CMC, Tanita MT, Festti J, Cardoso LTQ, Veiga CFF, et al. Nursing Activities Score and workload in the intensive care unit of a university hospital. Rev Bras Ter Intensiva. 2014;26(3):292-8.

17. Nogueira LS, Domingues CA, Poggetti RS, Sousa RM. Nursing workload in intensive care unit trauma: analysis of associated factors. PLoS One. 2014; 9(11):e112125.

18. Sousa CR, Gonçalves LA, Toffoleto MC, Leão K, Padilha KG. Preditores da demanda de trabalho de enfermagem para idosos internados em unidade de terapia intensiva. Rev Lat Am Enfermagem. 2008;16(2):218-23.

19. Ciampone JT, Gonçalves LA, Maia FOM, Padilha KG. Necessidades de cuidados de enfermagem e intervenções terapêuticas em Unidade de Terapia Intensiva: estudo comparativo entre pacientes idosos e não idosos. Acta Paul Enferm. 2006;19(1):28-35.

20. Sousa RMCD, Padilha KG, Nogueira LDS, Miyadahira AMK, Oliveira VCRD. Nursing workload among adults, elderly and very elderly patients in Intensive Care Unit. Rev Esc Enferm USP. 2009;43(n.spe2):1284-91.

21. Schein LE, Cesar JA. Perfil de idosos admitidos em unidades de terapia intensiva gerais em Rio Grande, RS: resultados de um estudo de demanda. Rev Bras Epidemiol. 2010;13(2):289-301.

22. Gomes GB, Gomes VRR. Perfil do idoso internado em UTI do interior paulista. Rev Cient UNIFAE. 2011;5(2):41-6.

23. Novaretti MC, Santos Ede V, Quitério LM, Daud-Gallotti RM. Sobrecarga de trabalho da Enfermagem e incidentes e eventos adversos em pacientes internados em UTI. Rev Bras Enferm. 2014;67(5):692-9.

24. Ahmed AH, Thongprayoon C, Schenck LA, Malinchoc M, Konvalinová A, Keegan MT, et al. Adverse in-hospital events are associated with increased in-hospital mortality and length of stay in patients with or at risk of acute respiratory distress syndrome. Mayo Clin Proc. 2015;90(3):321-8

25. Baines RJ, Langelaan M, de Bruijne MC, Wagner C. Is researching adverse events in hospital deaths a good way to describe patient safety in hospitals: a retrospective patient record review study. BMJ Open. 2015;5(7):e007380.

26. Pedreira LC, Brandão AS, Reis AM. Evento adverso no idoso em Unidade de Terapia Intensiva. Rev Bras Enferm. 2013;66(3):429-36.

27. Stelfox HT, Bagshaw SM, Gao S. A retrospective cohort study of age-based differences in the care of hospitalized patients with sudden clinical deterioration. J Crit Care. 2015;30(5):1025-31.

28. World Health Organization. Brazil: Who statistical profile [Internet]. Geneva: WHO; 2016 [cited 2016 Sept 08]. Available from: http:// www.who.int/gho/countries/bra.pdf?ua=1

29. Instituto Brasileiro de Geografia e Estatística. Expectativa de vida da população: ambos os sexos [Internet]. Rio de Janeiro: IBGE; 2016 [citado 2016 set. 08]. Disponível em: http://www.ibge.gov.br/home/estatistica/populacao/tabuadevida/2013/defaulttab_xls.shtm

Financial support

Coordenação de Aperfeiçoamento de Pessoal de Nível Superior (CAPES); Fundação de Amparo à Pesquisa de Estado de São Paulo (FAPESP); Conselho Nacional de Desenvolvimento Científico e Tecnológico (CNPq) and Fundación Mapfre. 